\title{
Differences of Gender in Oral and Written Communication Apprehension of University Students
}

\author{
Marlene Loureiro ${ }^{1}\left(\mathbb{D}\right.$, Norberto Loureiro ${ }^{1,2}$ and Rui Silva ${ }^{3, *} \mathbb{C}$ \\ 1 LABCOM, University of Trás-os-Montes e Alto Douro, 5000-801 Vila Real, Portugal; \\ mloureiro@utad.pt (M.L.); norberto.loureiro@ipb.pt (N.L.) \\ 2 Department of Business and Social Sciences, Polythecnic Institute of Bragança, 5300-252 Bragança, Portugal \\ 3 CETRAD, University of Trás-os-Montes e Alto Douro, 5000-801 Vila Real, Portugal \\ * Correspondence: ruisilva@utad.pt
}

Received: 23 November 2020; Accepted: 7 December 2020; Published: 14 December 2020

\begin{abstract}
Oral and written skills are increasingly considered to be essential tools in the job market for the success of any worker, and are thus called soft skills. Nevertheless, most graduates who enter the labor market experience difficulties in the apprehension of communication, not only with regard to writing, but also in oral communication. These difficulties are also noticeable in the classroom, for instance when students need to participate by expressing their doubts when they have to present research work within the curricular units they attend, or when they have to write their answers in assessment tests. In this paper, we explore the communication skills of students from different graduate degrees $(n=345)$ in order to understand how they prepare for oral and written communication. We made use of the Personal Report of Communication Apprehension (PRCA), validated by McCroskey, Beatty, Kearney, and Plax (1985), in order to understand students' oral communication apprehension. To understand the levels of written communication apprehension, we applied the Daly-Miller Writing Apprehension Test (DMWA). We thus analyzed the communicational skills and the communication apprehension of students from social and human sciences courses in order to understand how they prepare for oral and writing communication, and whether there were differences between genders and between different graduate courses regarding communication apprehension. The main results of this research confirm that the students experienced difficulties with and fear of communication, especially for oral communication. Furthermore, the results indicate that female students showed more significant levels of anxiety with regard to oral and written communication than male students. This exploratory study also makes it possible to distinguish areas of communication apprehension according to the different genders, and even with regard to the degree courses students belonged to.
\end{abstract}

Keywords: gender; communication apprehension; oral communication apprehension; writing communication apprehension; higher education

\section{Introduction}

Nowadays, oral and written communication skills are recognized and valued in all professional areas. For example, management professionals consider oral and written communication skills as essential tools for the success of any business manager. Although there have been several attempts to improve these skills in students, the results are still unsatisfactory. This difficulty is noticeable in the classroom when students must speak to explain their doubts, give oral presentations of their research work carried out in the curricular units, or answer written tests.

The literature related to communication sciences argues that the apprehension of communication is an essential factor that renders students ineffective at both oral and written skills. There is no doubt 
that graduates who go into the job market need more knowledge and skills than they acquire through the academic background of their area of training. They also need a plethora of other non-specific skills, namely communicative skills [1]. In this sense, higher education institutions are experiencing a need to improve their students' communication skills so that they can enter the job market more successfully in the future. Many teachers and trainers have realized the importance of developing communication skills for, first, the academic success, and then, the professional success, of their students. Employers themselves are increasingly aware of communicative needs and of the communicative skills required of a successful professional [2]. Effectively, in the globalized and dynamic business world of today, in which there are more and more employers, good oral and written communication skills are considered to be fundamental when decisions are being made about hiring workers or promoting them [3].

Thus, teachers and other trainers at various levels of education should promote communication skills, not only written, but also oral communication skills, because it is a fact that students have intrinsic fears about tasks involving oral and written communication. Thus, this exploratory study aims to (1) analyze the communication apprehension of students from social and human sciences courses, (2) find out if there are differences in oral and written communication apprehension levels, and (3) understand if there are differences in oral and written communication apprehension levels between genders and between graduate courses.

\section{Literature Review}

\subsection{Communication Apprehension}

McCroskey [4] defines communication apprehension (CA) as "an individual's level of fear and anxiety associated with either real or anticipated communication with another person" (p. 78). Individuals who are apprehensive about participating in actual communication situations are less able to communicate effectively. Individuals with high levels of CA are afraid to speak, and therefore naturally avoid doing so [5].

The question of students' fears and anxieties about CA has been studied in the literature since the 1940s [1]. Every individual has different levels of apprehension, resulting in various individual differences in communicative effectiveness or in the desire for communication. These differences tend to produce acute manifestations of anxiety when the individual is communicating orally or in writing.

In its broadest sense, CA consists of both apprehension towards oral communication and apprehension towards written communication [6]. There are, therefore, two generic forms of CA-oral and written. Oral communication apprehension (OCA) is defined as the fear or anxiety that an individual has regarding real or anticipatory situations of oral communication with another individual or individuals [4]. A person with a high CA has negative feelings about communication that outweigh the benefits he/she feels can be gained from it. In order to measure the apprehension of oral communication, we used the Personal Report of Communication Apprehension (PRCA) [7]. Written communication apprehension (WCA) is defined as the fear of writing. Students with WCA view writing as a punishment and avoid tasks that involve it. To measure the levels of WCA, we applied the Daly-Miller Writing Apprehension Test (DMWA) [8].

\subsubsection{Oral Communication Apprehension}

The existence of many problems in OCA is ubiquitous [9]. Significant studies demonstrate that there are many negative consequences when an individual has difficulties in the field of OCA [1]. When confronted with OCA situations, some individuals report fear, tension, and some physical symptoms, such as an increased heart rate and increased sweating [10]. Nevertheless, most suffer in silence and are not aware that this is a common lament.

Situations involving OCA are public speaking, meetings, group talking, and oral presentations, which can easily be transferred to the labour market, which should be addressed by teachers 
trainers $[4,9,11-13]$. Like CA, there are two approaches to reducing OCA, including behavioural interventions and pedagogic interventions [14]. The behavioural process works with the individual's psychological and physiological state, with his attitude toward communication, and the underlying fear associated with apprehension. Behavioural intervention includes techniques such as systematic desensitization, cognitive modification, and visualization. Systematic desensitization involves relaxation exercises, and this form of treatment trains a person to perceive the public as "non-threatening rather than threatening" and aims to reduce the fear associated with public speaking [15]. Cognitive modification focuses on the person's beliefs, and it tries to change the way a person sees communication tasks and decreases any threat or punishment [16]. Visualization allows the speaker to imagine the successful completion of a communication assignment. Pedagogical approaches differ from behavioural approaches in that they focus more directly on communication tasks, and seek to reduce apprehension by concentrating on the communication competence required to communicate effectively. The central pedagogical interventions are skills training and actual public speaking.

In addition to behavioural and pedagogical interventions in OCA treatment, another critical factor in higher education is creating a supportive and positive classroom environment [9]. OCA in the classroom focuses primarily on the apprehension felt by being evaluated, and the interpersonal environment within the school also influences it. Booth-Butterfield (1988) advocates that anxiety in the classroom can be moderate by manipulating the context (interpersonal, group, classroom, and public speaking), by motivating students, and by making the tasks more friendly (setting up a communication situation with a friend, not a strange). Teachers have an essential role, and teaching techniques should help students handle apprehension feelings. Thus, the best treatment for OCA should be a combination of behavioural and pedagogical interventions in a supportive and positive environment [9].

\subsubsection{Written Communication Apprehension}

Some individuals experience writing as a very challenging task [17]. Writing is a common task throughout the entire the teaching-learning process in schools and universities, as well as when people look for a job or occupation. Nonetheless, because of the complexity of writing, writing tasks tend to increase students' anxiety levels and can lead to negative attitudes towards writing and, consequently, avoiding it [18].

WCA is defined as a psychological construct associated with a person's predisposition to avoid situations requiring writing, especially if they are accompanied by some evaluation $[19,20]$. The term WCA was used by Daly and Miller [8] to refer to a general avoidance of writing and of situations perceived by an individual to potentially require some amount of writing, accompanied by the potential evaluation of that writing. A highly apprehensive person finds the experience of writing more punishing than rewarding and, consequently, avoids it [21]. Thus, highly anxious people tend to choose and sign up for select academic majors and jobs that are perceived, by them, as having lower writing requirements [21]

According to Daly [21], writing apprehension overwriting may play some role in the perceptions teachers (at least female teachers) form of students, as those responding readily to writing tasks may be seen more positively than those who are seen to be responding hesitantly. Students with a high level of WCA produce work of a lower quality than low apprehensive writers, avoiding writing tasks and procrastinating. Consequently, an elevated WCA may impact the writing performance, which means that highly anxious individual's written products may make them appear to be less smart than they are [22]. Thus, WCA interferes with writing skill development.

\subsection{Gender and Communication Apprehension}

Nowadays, society believes in equality between men and women. Nevertheless, what we observe in everyday life is different. We note that men and women are different, particularly concerning communication and discursive interaction, as they do not always interpret language/messages in the same way [23-27]. The idea that men and women have different conversational styles is already 
widespread. It is common to find books on psychology and anthropology, including chapters about understanding the opposite sex.

There are several reasons to justify gender differences concerning the use of language, namely, biological, psychological, and sociological reasons, as well as differences regarding the distribution of power in society, where men have more power than women, becoming dominant, particularly in social interaction [23]. In terms of gender as an essential variable to communication apprehension, it is crucial to note that this aspect is socially constructed and might involve other factors or reasons, depending on the context [13]. Some researchers argue that in a patriarchal society, women are silenced, and so they developed fear and anxiety to express themselves [24-26]. In this sense, women prefer to write instead of speaking orally in public [27].

The results of research on gender differences in communication apprehension are not conclusive [3], as some studies confirmed the existence of gender differences in favour of one of the sexes. In contrast, others asserted that gender plays no role in WCA [28]. For example, Masse and Popovich [29] say there is no evidence that there are differences in apprehension due to gender. On the other hand, Daly and Miller (1975c) noted potential sex differences in WCA according to responses to the instrument. In some studies, males were found to be significantly higher in apprehension than females $[21,30]$. However, some studies identified a higher WCA among women [31,32].

Regarding oral apprehension, females present higher levels of apprehension than males [33-36]. Arquero et al. [14] argue that females record higher apprehension scores and, thus, they conclude that gender is a significant variable for OCA, especially in formal settings. In addition, Simons et al. [37] found that female accounting and management students were more apprehensive about oral communication than their male counterparts.

Therefore, in numerous research on communication apprehension, gender has been a variable that has been taken into account, although prior research concerning the impact of gender on OCA has produced conflicting results [3]. On the other hand, other research on the relationship between gender and the choice of degree programmes in higher education and in employment opportunities [38] indicate differences in attitudes towards employability skills between male and female graduates. Furthermore, graduates' perceptions of their capabilities to deliver specific transferable skills highlighting significant gender differences, with females demonstrating less confidence in their problem-solving and communications skills [38-40]. According to these data, we consider that gender can be an essential variable in analysing communication apprehension in higher education, as men and women have different attitudes towards communication and communicative skills.

\section{Materials and Methods}

This is a quantitative study about oral (OCA) and written communication apprehension (WCA) that collected data through a questionnaire survey. We applied the Personal Report of Communication Apprehension (PRCA) from McCroskey et al. [7] in order to collect oral communication apprehension results. Furthermore, we also used the Daly-Miller Writing Apprehension Test (DMWA) from Daly and Miller [8] to collect data about written communication apprehension (WCA).

The data were treated with SPSS 25 software, applying several statistical tests of validity and reliability. As this article intends to analyze the OCA and WCA among social sciences students (degree courses surveyed: economics, management, languages and business relations, tourism, and communication sciences), we measured the oral and written communication apprehension levels among students in order to identify the existence of differences between genders.

\subsection{Sample Characterization}

In this study, students were divided into five areas of knowledge (degree courses surveyed: economics, management, languages and business relations, tourism, and communication sciences) all belonging to social sciences and humanities. Students from the Department of Social and Human Sciences of a public university in the North of Portugal were chosen to participate in the study. 
The choice of several courses in the social sciences area was made in order to obtain results from different knowledge areas. Thus, it was possible to consider other realities for a more in-depth analysis. The students who participated in the study signed an authorization and confidentiality document. The participants were students between 18 and 22 years old, an average of 19.55 years, with $45 \%$ male and $55 \%$ female students. A total of 345 questionnaires were collected from a total population of 2500 students studying in sub-areas of social sciences.

\subsection{Measuring Instruments}

To collect the data, two questionnaires were used in the classroom, composed of two parts, namely: (1) socio-demographic variables and (2) constructs of the model under analysis. As can be seen in Table 1, the research model for OCA had four constructs with a total of 24 items. The research model for WCA had four constructs with a total of 26 items, as seen in Table 2. Both questionnaires were measured using the Likert Scale (1 to 5$)$, ranging from "totally agree" to "totally disagree". The questionnaires were applied at the end of the semester of classes, after permission from the Higher Education Institutions (HEI) that participated in the study.

Table 1. Personal Report of Communication Apprehension (PRCA) measurement instruments.

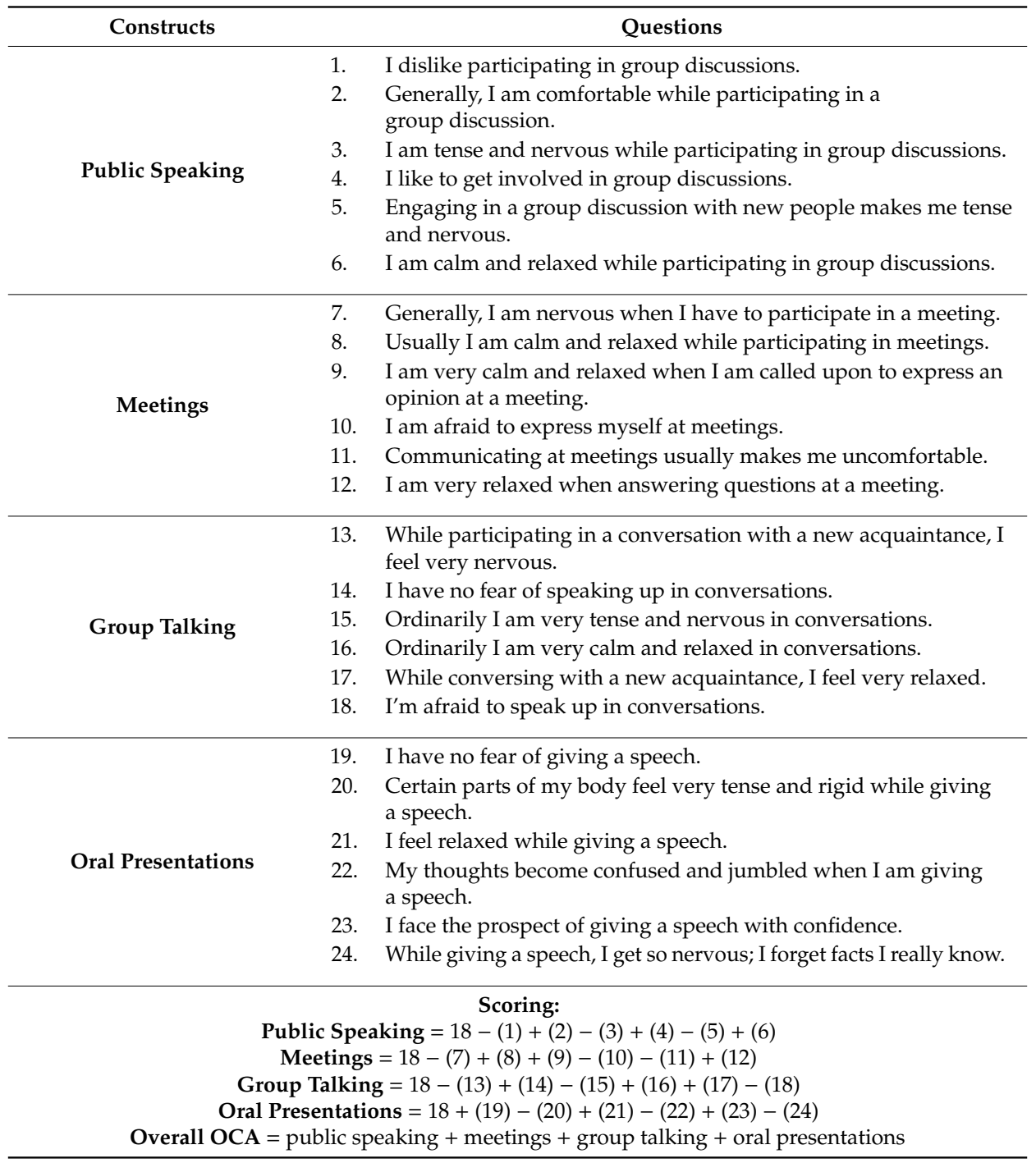


Table 2. Daly-Miller Writing Apprehension Test (DMWA) measurement instruments.

\begin{tabular}{|c|c|}
\hline Constructs & Questions \\
\hline Positivity towards writing & $\begin{array}{l}\text { 1. I avoid writing } \\
\text { 3. I look forward to writing down my ideas. } \\
\text { 5. Taking a composition course is a very frightening experience. } \\
\text { 8. Expressing ideas through writing seems to be a waste of time. } \\
\text { 9. I would enjoy submitting my writing to magazines for evaluation and publication. } \\
\text { 10. I like to write my ideas down. } \\
\text { 15. I enjoy writing. } \\
\text { 17. Writing is a lot of fun. } \\
\text { 19. I like seeing my thoughts on paper. }\end{array}$ \\
\hline Negativity towards writing & $\begin{array}{l}\text { 7. My mind seems to go blank when I start to work on a composition. } \\
\text { 13. I'm nervous about writing. } \\
\text { 14. People seem to enjoy what I write. } \\
\text { 16. I never seem to be able to write down my ideas. } \\
\text { 18. I expect to do poorly in composition classes even before I enter them. } \\
\text { 21. I have a terrible time organizing my ideas in a composition course. } \\
\text { 22. When I hand in a composition, I know I'm going to do poorly. } \\
\text { 23. It's easy for me to write suitable essays. } \\
\text { 24. I don't think I write as well as most other people. } \\
\text { 26. I'm no good at writing. }\end{array}$ \\
\hline Evaluation apprehension & $\begin{array}{l}\text { 2. I have no fear of my writing being evaluated. } \\
\text { 4. I am afraid of writing essays when I know they will be considered. } \\
\text { 6. Handing in a composition makes me feel good. } \\
\text { 25. I don't like my compositions to be evaluated. }\end{array}$ \\
\hline Self-efficacy and writing & $\begin{array}{l}\text { 11. I feel confident in my ability to clearly express my ideas in writing. } \\
\text { 12. I like to have my friends read what I have written. } \\
\text { 20. Discussing my writing with others is an enjoyable experience. }\end{array}$ \\
\hline $\begin{array}{r}\text { Positivity to } \\
\text { Negativity toward } \\
\text { Overall WCA = }\end{array}$ & $\begin{array}{l}\text { Scoring: } \\
\text { ards writing }=78+(1)-(3)+(5)+(8)-(9)-(10)-(15)-(17)-(19) \\
\text { writing }=78+(7)+(13)-(14)+(16)+(18)+(21)+(22)-(23)+(24)+(26) \\
\text { Evaluation apprehension }=78-(2)+(4)-(6)+(25) \\
\quad \text { Self-efficacy and writing }=78-(11)-(12)-(20) \\
78+\text { positive statements values }(\mathrm{PSV})-\text { negative statements values (NSV) } \\
\quad \text { *PSV questions }=1 ; 4 ; 5 ; 7 ; 8 ; 13 ; 16 ; 18 ; 21 ; 22 ; 24 ; 25 ; 26 \\
\quad \text { * NSV questions }=2 ; 3 ; 6 ; 9 ; 10 ; 11 ; 12 ; 14 ; 15 ; 17 ; 19 ; 20 ; 23\end{array}$ \\
\hline
\end{tabular}

\subsection{Validity and Reliability of the Measurement Model}

The validity analysis of PRCA and DMWA was done using the exploratory factor analysis (EFA) and the reliability analysis was done through Cronbach's Alpha, evidencing the statistical properties of this instrument as well as its division into four factors. In addition, the Kaiser-Meyer-Olkin adequacy measure (KMO) was calculated and obtained adequate results (Tables 3 and 4). 
Table 3. Exploratory factor analysis (EFA) of PRCA.

\begin{tabular}{|c|c|c|c|c|c|}
\hline \multicolumn{6}{|c|}{ Round Component Matrix } \\
\hline \multirow{2}{*}{ Constructs } & \multirow{2}{*}{ Variables } & \multicolumn{4}{|c|}{ Factors } \\
\hline & & 1 & 2 & 3 & 4 \\
\hline \multirow{6}{*}{ Public Speaking } & Speaking1 & 0.667 & & & \\
\hline & Speaking2 & 0.662 & & & \\
\hline & Speaking3 & 0.605 & & & \\
\hline & Speaking4 & 0.712 & & & \\
\hline & Speaking5 & 0.660 & & & \\
\hline & Speaking6 & 0.711 & & & \\
\hline \multirow{6}{*}{ Meetings } & Meetings1 & & 0.682 & & \\
\hline & Meetings2 & & 0.747 & & \\
\hline & Meetings3 & & 0.567 & & \\
\hline & Meetings4 & & 0.605 & & \\
\hline & Meetings5 & & 0.619 & & \\
\hline & Meetings6 & & 0.897 & & \\
\hline \multirow{6}{*}{ Group Talking } & Talking1 & & & 0.550 & \\
\hline & Talking2 & & & 0.528 & \\
\hline & Talking3 & & & 0.718 & \\
\hline & Talking4 & & & 0.664 & \\
\hline & Talking5 & & & 0.591 & \\
\hline & Talking6 & & & 0.729 & \\
\hline \multirow{6}{*}{ Oral Presentations } & Presentations1 & & & & 0.585 \\
\hline & Presentations2 & & & & 0.580 \\
\hline & Presentations3 & & & & 0.606 \\
\hline & Presentations4 & & & & 0.598 \\
\hline & Presentations5 & & & & 0.535 \\
\hline & Presentations6 & & & & 0.613 \\
\hline Cronbach Alpha Value & & 0.890 & 0.815 & 0.825 & 0.781 \\
\hline Cronbach Alpha Value for PRCA-24 (total) & & 0.920 & & & \\
\hline Kaiser-Meyer-Olkin & & 0.857 & & & \\
\hline
\end{tabular}

Table 4. Exploratory factor analysis (EFA) of DMWA.

\begin{tabular}{|c|c|c|c|c|c|}
\hline \multicolumn{6}{|c|}{ Round Component Matrix } \\
\hline \multirow{2}{*}{ Constructs } & \multirow{2}{*}{ Variables } & \multicolumn{4}{|c|}{ Factors } \\
\hline & & 1 & 2 & 3 & 4 \\
\hline \multirow{9}{*}{ Positivity towards writing } & PTW1 & 0.612 & & & \\
\hline & PTW3 & 0.545 & & & \\
\hline & PTW5 & 0.548 & & & \\
\hline & PTW8 & 0.658 & & & \\
\hline & PTW9 & 0.532 & & & \\
\hline & PTW10 & 0.617 & & & \\
\hline & PTW15 & 0.726 & & & \\
\hline & PTW17 & 0.632 & & & \\
\hline & PTW19 & 0.640 & & & \\
\hline \multirow{10}{*}{ Negativity towards writing } & NTW7 & & 0.568 & & \\
\hline & NTW13 & & 0.581 & & \\
\hline & NTW14 & & 0.388 & & \\
\hline & NTW16 & & 0.534 & & \\
\hline & NTW18 & & 0.582 & & \\
\hline & NTW21 & & 0.512 & & \\
\hline & NTW22 & & 0.628 & & \\
\hline & NTW23 & & 0.583 & & \\
\hline & NTW24 & & 0.572 & & \\
\hline & NTW26 & & 0.661 & & \\
\hline
\end{tabular}


Table 4. Cont.

\begin{tabular}{cccccc}
\hline & Round Component Matrix & & \\
Constructs & Variables & \multicolumn{3}{c}{ Factors } \\
\cline { 3 - 6 } & & $\mathbf{1}$ & $\mathbf{2}$ & $\mathbf{3}$ & $\mathbf{4}$ \\
\hline & EA2 & & & 0.549 \\
Evaluation apprehension & EA4 & & 0.637 \\
& EA6 & & 0.548 \\
& EA25 & & 0.594 \\
\hline & SEW11 & & & 0.620 \\
Self-efficacy and writing & SEW12 & & & 0.565 \\
& SEW20 & & & 0.551 \\
\hline Cronbach Alpha Value & & 0.834 & 0.876 & 0.712 & 0.702 \\
\hline Cronbach Alpha Value for PRCA-24 (total) & & 0.903 & & \\
\hline Kaiser-Meyer-Olkin & & 0.941 & & \\
\hline
\end{tabular}

\section{Results and Discussions}

\subsection{Validity and Reliability of PRCA and DMWA}

The results of the EFA and the reliability obtained in the statistical tests allow us to verify that there was sufficient evidence that the PRCA and DMWA had validity and reliability, as it had already been shown in previous studies $[17,41]$.

To verify if the factorial model agreed with the literature, the EFA of the original version of the scale was adapted to Portuguese. Factor extraction by the principal components method (PCM) and its oblique rotation, considering only values whose factors were $\geq 1$, resulted in a $\mathrm{KMO}=0.857$ for $\mathrm{PRCA}$ and $\mathrm{KMO}=0.941$ for DMWA, as well as a correlation matrix of four factors, which indicate $63.04 \%$ for the PRCA variance and $56.47 \%$ for DMWA. The factor that explained most of the variance was the factor extracted variation, which indicated $40.18 \%$ and $37.97 \%$, respectively. Other extractions were simulated, with a more significant number of factors maintaining the extraction criterion of $\geq 1$. However, the way the factors were distributed and the percentage of variance explained were in disagreement with the way the variables are usually organized in the various scientific studies [33].

Tables 3 and 4 present the exploratory factorial matrix of the 24 items of the PRCA and the 36 items of DMWA, as well as their respective factor loads, where we can see how the variables were distributed by the four factors resulting from the EFA. The Cronbach's Alpha value for the 24 items of the scale presented results that evidenced its robustness, standing at 0.920 to PCRA and 0.903 to DMWA. These results indicate that the data set is adequate for the factorial analysis.

The four factors obtained, all with loads higher than 0.5 , were conceptually the most indicated in communication apprehension and written apprehension contexts. To test each of the individual scales' reliability, we extracted the Cronbach Alpha, all exceeding the acceptable level of 0.7.

\subsection{Oral Communication Apprehension}

Table 5 shows the global mean scores and respective standard deviations for the whole sample and the samples by degree course, presenting the total data and the data for gender. Through this table, we can see the male and female results, and results for both genders regarding public speaking, work meetings, group work, and oral presentations. There are differences between these groups for the different oral communication apprehension levels. 
Table 5. Oral communication apprehension (OCS) students' scores by gender and degree courses.

\begin{tabular}{|c|c|c|c|c|c|c|}
\hline \multicolumn{7}{|c|}{ Oral Communication Apprehension Constructs } \\
\hline Course & Gender & Public Speaking & Meetings & Group Talking & Oral Presentations & Total OCA $^{1}$ \\
\hline \multirow{3}{*}{ Full Sample } & Male & 16.23 & 17.15 & 15.49 & 16.75 & 65.61 \\
\hline & Female & 17.69 & 18.90 & 15.62 & 18.66 & 70.87 \\
\hline & Total & 17.25 & 18.37 & 15.58 & 18.08 & 69.28 \\
\hline \multirow{3}{*}{ Economics } & Male & 15.38 & 17.53 & 15.53 & 17.07 & 65.53 \\
\hline & Female & 18.51 & 20.14 & 17.25 & 20.59 & 76.51 \\
\hline & Total & 17.50 & 19.30 & 16.70 & 19.45 & 72.95 \\
\hline \multirow{3}{*}{ Management } & Male & 16.50 & 16.93 & 16.00 & 15.53 & 65.96 \\
\hline & Female & 17.76 & 19.11 & 16.00 & 17.64 & 70.52 \\
\hline & Total & 17.23 & 18.20 & 16.00 & 17.18 & 68.25 \\
\hline \multirow{3}{*}{ Languages and Business Relations } & Male & 17.72 & 18.36 & 15.00 & 18.81 & 69.90 \\
\hline & Female & 19.84 & 20.96 & 18.00 & 21.84 & 80.65 \\
\hline & Total & 19.21 & 20.18 & 17.10 & 20.94 & 77.45 \\
\hline \multirow{3}{*}{ Communication Sciences } & Male & 16.81 & 17.94 & 14.55 & 17.65 & 66.95 \\
\hline & Female & 17.17 & 18.35 & 14.66 & 18.16 & 68.36 \\
\hline & Total & 16.81 & 17.94 & 14.55 & 17.65 & 66.95 \\
\hline \multirow{3}{*}{ Tourism } & Male & 17.09 & 18.00 & 19.36 & 17.45 & 71.90 \\
\hline & Female & 16.89 & 17.52 & 15.63 & 17.21 & 67.26 \\
\hline & Total & 16.96 & 17.70 & 17.00 & 17.30 & 68.96 \\
\hline
\end{tabular}

When analyzing the full sample, we found that speaking at meetings was where students are less comfortable, with women achieving a higher score than men, corroborating previous studies [33-35]. However, most of the literature reviews [3,11-13] had the same results as this article. In the other research, public speaking was the most appreciated oral communication context, and, in this sense, with the highest score, reveals that students were usually more comfortable speaking in public than in oral presentations, group talking, and meetings. Our results were the same regarding female data, but we had different results for the male gender. Regarding the difference between men and women in the total results of all dimensions, women reached higher levels than men in all OCA constructs [36], resulting in the total OCA also being higher for the female gender (70.87) compared with the male gender (65.61). In the full sample, the total OCA values were within the average, with typical results (50-80) [42]. Considering these results, we could identify the main difficulties as being oral communication apprehension for the women group [35].

Considering the OCA by categories, we found that women achieved higher scores than men in all dimensions of OCA. For women, the highest OCA values were in the meetings dimension, followed by oral presentations, public speaking, and group talking. Group talking was the dimension in which women were least apprehensive about intervening orally [33-35].

Regarding men, the dimension in which they revealed the most significant oral apprehension was in meetings, followed by oral presentations, group talking, and public speaking. The public speaking dimension was the one in which men showed the least oral apprehension [43].

The differences between gender, where women had OCA scores superior to men in all items, corroborated previous studies that revealed that men presented less oral communication apprehension $[14,33,37]$.

We did not find any students where the total results were below the average OCA $(<50)$ or above the average $(>80)$, corroborating more recent studies in which such results also occurred $[12,35,36,42,44]$.

Regarding the results according to courses, we found that concerning the total OCA in the full sample, we OCA was within the average range of expected results (50-80) [42]. Regarding the results for gender, the results remained within the average, but women had slightly higher OCA levels than men in all degree courses, except tourism. The more detailed analysis allowed us to verify that the OCA for tourism was higher for men (71.90). The degrees where women had higher OCAs were languages and business relations (80.65). Overall, the degrees with a total higher OCA were languages and business relations (77.45), much to our suprise. This type of course with a lower OCA would be as a result of its curricular structure and working methods. Communication sciences also had a lower 
OCA (66.95). When we focussed our analysis on the various dimensions of OCA per degree course, we found that both men and women had higher OCA values in all dimensions for the languages and business relations degrees, except in the group talking dimension, corresponding to men, who showed the highest value in the tourism course. Finally, through a full sample ranking, we verified the degree courses where OCA was higher: first being languages and business relations (77.45), second being economics (72.95), third being tourism (68.96), fourth being management (68.25), and fifth being communication sciences (66.95). When ranking the highest OCA by gender, for males, from highest lowest was as follows: tourism (71.90), languages and business relations (69.90), communication sciences (66.95), management (65.96), and economics (65.53). For females, the OCA from highest to lowest was as follows: languages and business relations (80.65), economics (76.51), management (70.52), communication sciences (68.36), and tourism (67.26).

Figure 1 shows the results of the students' oral communication apprehension scores graphically according to gender and degree courses, as another way to interpret and compare the results. In each column is the OCA dimension's results and the total values resulting from the sum of all of the scales that were included in the total OCA.

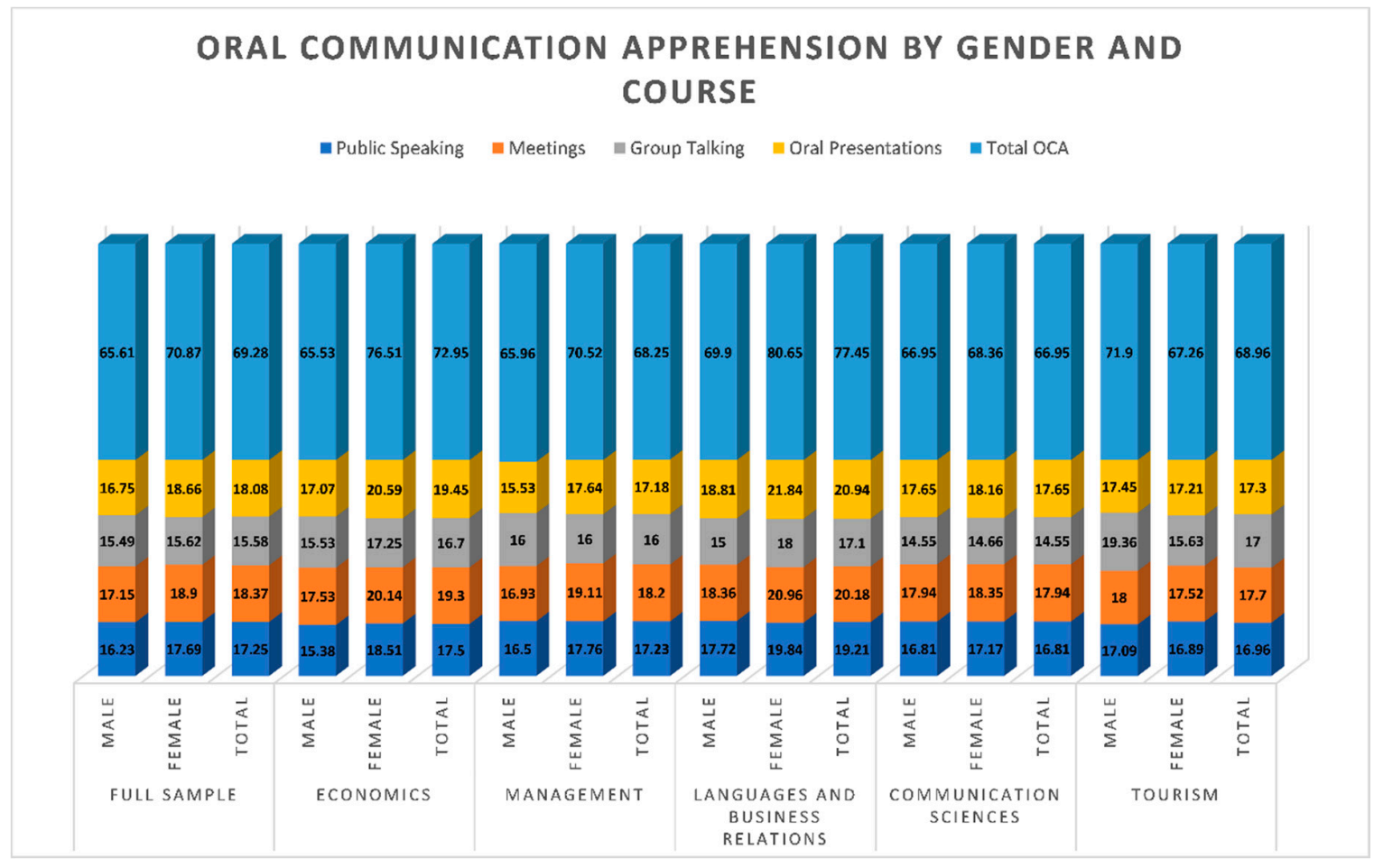

Figure 1. Oral communication apprehension students' scores according to gender and degree courses.

To verify if the differences observed in the total results of oral communication apprehension were statistically significant, we performed an inferential analysis using ANOVA for the variable total CA and for the factors of gender and degree course. In Table 6, we can observe the variables for degree course and gender. Both the gender and degree course lines allow us to visualize the effects of these variables on the total CA. As $p<0.05$ for both, we can see that gender and degree course influenced the overall CA.

After the analysis of variance (ANOVA) was carried out, post hoc tests were necessary to identify which of the pairs of groups differed. In Table 7, we also performed a post hoc test to determine the degree of means. The OCA average scores for each degree were statistically different, but only for the communication sciences (66.9) and languages (77.5) degrees. For all of the other degrees, the OCA scores were similar. Communication course students had a lower OCA for oral communication than the language course students. Even so, both of the average scores were in the OCA average range. 
Table 6. Tests of between-subject effects.

\begin{tabular}{cccccc}
\hline \multicolumn{6}{c}{ Dependent Variable: Overall CA } \\
\hline Source & Type III Sum of Squares & df & Mean Square & F & Sig. \\
\hline Corrected Model & 7484.721 & 9 & 831.636 & 3.393 & 0.001 \\
Intercept & $1,026,674.448$ & 1 & $1,026,674.448$ & 4189.304 & 0.000 \\
Course & 2824.703 & 4 & 706.176 & 2.882 & 0.023 \\
Gender & 1584.057 & 1 & 1584.057 & 6.464 & 0.011 \\
Course $\times$ Gender & 1210.315 & 4 & 302.579 & 1.235 & 0.296 \\
\hline
\end{tabular}

Table 7. Post hoc tests.

\begin{tabular}{cccc}
\hline \multicolumn{4}{c}{ Overall CA } \\
\hline \multicolumn{3}{c}{ Ryan-Einot-Gabriel-Welsch Range } \\
Course & $\mathbf{N}$ & \multicolumn{2}{c}{ Subset } \\
\cline { 3 - 4 } & & $\mathbf{1}$ & $\mathbf{2}$ \\
\hline Communication Sciences & 170 & 66.9588 \\
Management & 72 & 68.6250 & 68.6250 \\
Tourism & 30 & 68.9667 & 68.9667 \\
Economics & 40 & 72.9500 & 72.9500 \\
Languages & 37 & & 77.4595 \\
Sig. & & 0.319 & 0.074 \\
\hline
\end{tabular}

The OCA scores according to gender (regardless of the degree they were) were statistically different. This means that the average OCA scores for all of the men (65.6) were statistically different from all of the women (70.9). Thus, women tended to have a slightly higher apprehension of oral communication than men. As the scores were in the middle range, we decided to disaggregate the scores by category for men and women, and by apprehension level (high, medium, and low; Table 8).

Table 8. Oral communication apprehension of students according to gender and OCA levels.

\begin{tabular}{cccc}
\hline Gender & High & Average & Low \\
\hline Male & 13 & 78 & 15 \\
Female & 75 & 142 & 26 \\
Total & 88 & 220 & 41 \\
\hline Level of OCA: high $(>80) ;$ average (50 to 80); low $(<50)$.
\end{tabular}

We found that the average level (50 to 80$)$ was the highest in the total sample. For men $(n=106)$, the vast majority $(74 \%)$ were in the average level $(50$ to 80$)$, followed by the low level $(<50)$ with $14 \%$, and the high level $(>80)$ with $12 \%$. For women, it was also found that the vast majority $(58 \%)$ of the results of the total OCA were in an average level (50 to 80$)$, followed by the high level $(>80)$ with $31 \%$, and the low level $(<50)$ with $11 \%$. As a result, the women had higher OCA levels than the men, because they were 19\% higher than men. This demonstrates the increased learning for oral communication shown by women. To determine whether the proportions were different for males and females (Table 9), we used nonparametric statistics (chi-squared analysis).

Table 9. Analysis.

\begin{tabular}{ccc}
\hline & Gender & Overall CA \\
\hline Chi-Square & $53,779^{\mathrm{a}}$ & $169,424^{\mathrm{b}}$ \\
$\mathbf{d f}$ & 1 & 73 \\
Asymp. Sig. & 0.000 & 0.000 \\
\hline
\end{tabular}

a 0 cells $(0.0 \%)$ have expected frequencies less than 5 . The minimum expected cell frequency is $174.5 .{ }^{\mathrm{b}} 74$ cells $(100.0 \%)$ have expected frequencies less than 5 . The minimum expected cell frequency is 4.7 . 


\subsection{Writing Communication Apprehension}

Table 10 displays the results of the WCA overall and by gender. The first conclusion from these results is that the total WCA scores were very close in both genders, averaging 60 to 96 points [30]. Both groups of students who scored in this range did not experience a significantly unusual writing apprehension level. However, the closer the score was to the limit of this range, namely scores close to 60 and 96, the more probability of experiencing feelings or behaviours characteristic of the next degree of scores [21]. A score of 78 placed a student, as a writer, on the mean, the middle point between two extremes for conditions recorded in a large sample of students. However, this kind of student should be aware that they may manifest signs of WCA in performing specific writing tasks or in writing with varying purposes for different types of audiences. While these groups may not experience harmful apprehension while writing an expositive essay, for example, they may experience excessive writing apprehension for a placement essay for faceless evaluators or in writing an in-class essay exam for a history professor [8].

When analyzing the results according to gender in the total sample, we found that, although the values were very close, men (88.59) revealed less WCA than women (88.23), corroborating previous studies [31,32]. For men, the dimension in which they showed the most WCA was self-efficacy and writing, followed by positivity towards writing, evaluation apprehension, and finally negativity towards writing. However, all values were in the mean, except negativity towards the writing dimension, which was below average. When values were in the range 97 to 130 , students had a low WCA level [28].

For the female gender, the same results were found for men according to size, although the score values were lower in all dimensions except positivity towards writing. No results were found in the 26 to 59 range, which means that neither men nor women were in a high WCA [32]. This means that none of these groups had a high level of WCA. A score in this range (26 to 59) means more severe anxiety. Students in this group were nervous about writing and were fearful of evaluation. Research shows that those who score extremely low in this range will not take a degree course, select a major, or accept a job they know involves writing [8].

Regarding the results according to degree courses, we found that, regarding the total WCA in the full sample, WCA was in the average range of expected results (60-96) [39]. Regarding the results according to gender, the results remained within the average, but women had slightly higher WCA levels than men in all courses except for management, languages, and business relations [32]. A more detailed analysis allowed us to verify that the degree course where WCA was higher for men was the management course (83.40), and for women it was the economics course (83.74). The course where the WCA overall was higher was economics (85.97). The communication sciences course was the one where the WCA was the lowest (90.04). When we focused our analysis on the various dimensions of the WCA per course, we found that men had higher WCA values for positivity towards writing, and self-efficacy and writing, in the management course; negativity towards writing in the tourism course; and evaluation apprehension in the languages and business relations courses. For women, they had higher WCA values in the economics course in all dimensions of the DMWA scale. Conversely, men had lower WCA values for positivity towards the writing dimension of communication sciences, negativity towards writing in economics, evaluation apprehension and self-efficacy and writing in tourism. Women had lower WCA values in positivity towards writing, and self-efficacy and writing, in communication sciences, and negativity towards writing, as well as evaluation apprehension, in management. 
Table 10. Writing communication apprehension students' scores according to gender and degree course.

\begin{tabular}{|c|c|c|c|c|c|c|}
\hline \multicolumn{7}{|c|}{ Writing Communication Apprehension Constructs } \\
\hline Course & Gender & Positivity towards Writing & Negativity towards Writing & Evaluation Apprehension & Self-Efficacy and Writing & Total WCA $^{1}$ \\
\hline \multirow{3}{*}{ Full Sample } & Male & 73.20 & 100.26 & 79.52 & 69.61 & 88.59 \\
\hline & Female & 74.21 & 99.83 & 78.69 & 69.49 & 88.23 \\
\hline & Total & 73.90 & 99.97 & 78.94 & 69.53 & 88.34 \\
\hline \multirow{3}{*}{ Economics } & Male & 71.92 & 103.07 & 79.69 & 69.92 & 90.61 \\
\hline & Female & 71.33 & 99.14 & 77.96 & 69.29 & 83.74 \\
\hline & Total & 71.52 & 100.42 & 78.52 & 69.50 & 85.97 \\
\hline \multirow{3}{*}{ Management } & Male & 71.13 & 98.46 & 79.10 & 68.70 & 83.40 \\
\hline & Female & 72.87 & 100.58 & 79.02 & 69.41 & 87.90 \\
\hline & Total & 72.14 & 99.69 & 79.05 & 69.11 & 86.00 \\
\hline \multirow{3}{*}{ Languages and Business Relations } & Male & 73.63 & 99.00 & 78.81 & 69.45 & 86.90 \\
\hline & Female & 74.69 & 100.50 & 78.57 & 68.57 & 88.34 \\
\hline & Total & 74.37 & 100.05 & 78.64 & 68.83 & 87.91 \\
\hline \multirow{3}{*}{ Communication Sciences } & Male & 74.85 & 101.50 & 79.71 & 70.04 & 92.11 \\
\hline & Female & 75.24 & 99.61 & 78.74 & 69.74 & 89.35 \\
\hline & Total & 75.14 & 100.08 & 78.98 & 69.82 & 90.04 \\
\hline \multirow{3}{*}{ Tourism } & Male & 73.60 & 98.20 & 80.50 & 70.30 & 88.60 \\
\hline & Female & 73.70 & 99.75 & 78.80 & 69.50 & 87.75 \\
\hline & Total & 73.66 & 99.23 & 79.36 & 69.76 & 88.03 \\
\hline
\end{tabular}

${ }^{1}$ Level of WCA: high (26 to 59$)$; average (60 to 96$)$; low (97 to 130). 
Finally, with a sample ranking, we verified the following courses where WCA was higher, from highest to lowest, namely, economics (85.97), management (86.00), languages and business relations (87.91), tourism (88.03), and communication sciences (90.04). When ranked according to gender, for males, from highest to lowest, was management (83.40), languages and business relations (86.90), tourism (88.60), economics (90.61), and communication sciences (92.11). For females, from highest to lowest, was economics (83.74), tourism (87.75), management (87.90), languages and business relations (88.34), and communication sciences (89.35).

In Figure 2, we can see the graphical results of the writing communication apprehension students' scores according to gender and degree courses, providing another way to interpret and compare results. In each column is the OCA dimension's results and the total values resulting from the sum of all of the scales that give rise to the total WCA.

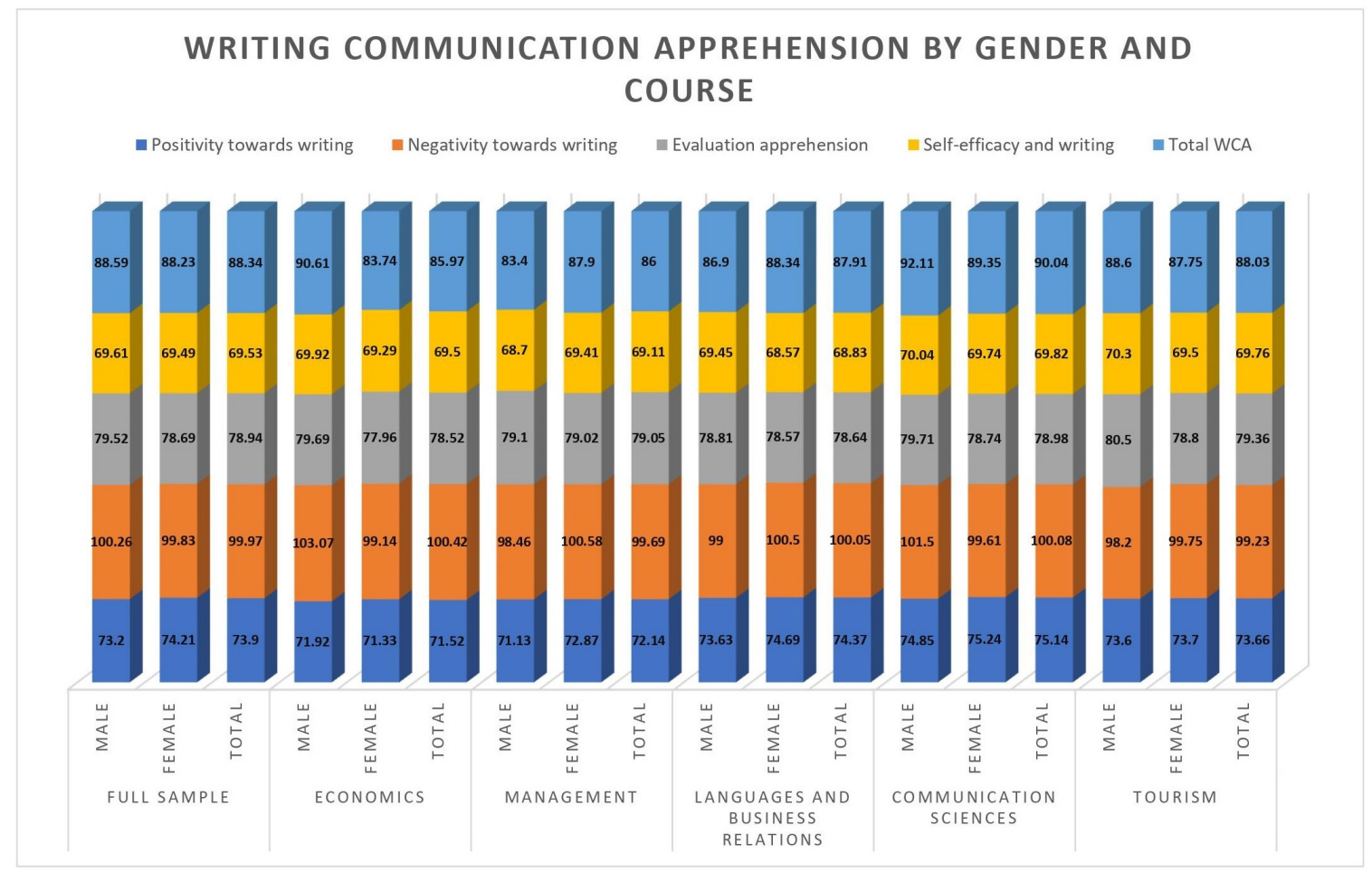

Figure 2. Writing Communication Apprehension students' scores by gender and degree courses.

To verify if the differences observed in the total results of writing communication apprehension were statistically significant, we performed an inferential analysis, using ANOVA, for the total variable WCA and for the factors of gender and course. We also performed a post hoc test to determine the degree of means (Appendix A). In Table 11, we can observe the variables for course and gender. Both gender and course allow for visualizing the effect of these variables on the total CA. As $p<0.05$, both gender and course did not affect the overall WCA.

Table 11. Tests of between-subject effects.

\begin{tabular}{cccccc}
\hline \multicolumn{7}{c}{ Dependent Variable: Overall WCA } \\
\hline Source & Sum of Squares & df & Mean Square & F & Sig. \\
\hline Corrected Model & 2136.389 & 9 & 237.377 & 0.938 & 0.492 \\
Intercept & $1,599,156.693$ & 1 & $1,599,156.693$ & 6319.142 & 0.000 \\
Course & 1278.485 & 4 & 319.621 & 1.263 & 0.284 \\
Gender & 42.916 & 1 & 42.916 & 0.170 & 0.681 \\
Course $\times$ Gender & 970.669 & 4 & 242.667 & 0.959 & 0.430 \\
\hline
\end{tabular}




\section{Conclusions}

This study aimed to verify the differences in oral and written communication apprehension in higher education students according to genders and degree courses. In this sense, it contributed to the advancement of the literature in this area of knowledge, allowing for a better understanding of communication apprehension levels among students of different genders, emphasizing the need to develop strategies to improve students' communication skills in higher education. In this sense, the study is a pedagogical contribution, alerting teachers to the importance of developing strategies in class that promote the reduction of oral and writing communication apprehension among students.

We found that the female students who participated in this research revealed a higher OCA than male students in all items being analysed. In women, the highest OCA values were found in the meetings dimension, followed by oral presentations, public speaking, and finally, group talking, which is the dimension in which women are the least apprehensive about intervening orally. The same occurred for the male gender, but the last dimension was public speaking not group talking. This dimension is the one that men revealed the least oral apprehension. These results continue to highlight what the previous literature had already advocated, demonstrating that there are oral and writing communication apprehension differences between men and women, corroborating gender communication differences regarding communication skills and competencies.

Concerning the total OCA, the results from the sum of the four items showed that women led, but both sexes were within the OCA average stated in the literature. Regarding WCA, the results by gender were very close, but generally, men revealed less WCA than women. For men, the dimension in which they showed most WCA was self-efficacy and writing, followed by positivity towards writing, evaluation apprehension, and, finally, negativity towards writing. However, all values were within the average, except for negativity towards the writing dimension, which was below average. In the female gender, the same results according to size were found as for males, although the score values were lower in all dimensions. These results are in line with previous literature, as women are more reticent and fearful about communicating in public and are less participative than men in public communicative settings.

Regarding OCA results per degree course, we found that the course where OCA was superior in men was tourism. Women had a higher OCA for language and business relations. We found that both men and women had higher OCA scores in all dimensions on the languages and business relations course, except for the group talking dimension, where men had the highest score for tourism Finally, the full sample ranking showed the courses where OCA was the highest was languages; if the ranking according to gender we men led in the tourism course and for women it was languages. Regarding the WCA results according to course, we verified that WCA was higher in men for management, and for women economics. These results corroborate the relevance of this approach in this research to assess the formative and teaching needs in the area of the communicative skills necessary for the different courses of higher education, and to make teachers aware of the need to develop these communicative competencies, which are transversal to any course, job, or professional occupation.

In summary, the quantitative data analyzed in this study corroborate some previous studies. In general, a majority of studies had similar conclusions. As usual, men had lower scores of communication apprehension than women. These results allow us to verify that OCA and WCA levels may change depending on the context, the size of the classes, and the area of knowledge in which the studies are carried out. The overall results of this study indicate that public speaking and group talking are the OCA items in which students show more difficulties, and self-efficacy and writing is the WCA item with the worst score for both genders, probably because, throughout their academic career, they have rarely been challenged to participate in these communication contexts. Thus, it will be interesting to use the various studies carried out in this area, as well as the results of the present investigation, to encourage the involvement of higher education students in more public lectures, in both an academic and non-academic context, so as to combat the fear of making communication errors, making them better able to face this critical challenge. In conclusion, all scientific 
and academic people, including teachers, researchers, and students, must be aware of the importance of developing this type of communication skill in order to achieve the desired personal, academic, and professional success.

\section{Limitations and Future Recommendations}

One of the limitations of this study is the sample size and its specificity, focusing only on higher education students of social sciences and humanities courses. In this sense, we should extend this approach to students from other knowledge areas and respective courses.

This research also suggests the increasing need for educational institutions to promote an ideal learning environment in which teachers can inspire their students to communicate orally. On the other hand, these results suggest the most critical communication items consider, as well as the techniques and areas of intervention to improve the communication process and to provide clues for future research in this area of knowledge.

We recommend that future studies approach students' communication experiences from other universities in different contexts of learning in order to compare the results with those of the present study. It would be interesting to know and identify if another sample of students would show differences in OCA and WCA levels between areas of knowledge and different higher education grade levels.

Author Contributions: Formal analysis, R.S.; Investigation, N.L. and R.S.; Methodology, R.S.; Project administration, M.L. and R.S.; Supervision, M.L.; Writing-original draft, M.L., N.L. and R.S.; Writing-review \& editing, M.L. and R.S. All authors have read and agreed to the published version of the manuscript.

Funding: This work is supported by national funds, through the FCT-Portuguese Foundation for Science and Technology under the project UIDB/04011/2020.

Acknowledgments: The authors gratefully acknowledge the University of Trás-os-Montes e Alto Douro and CETRAD (Centre for Transdisciplinary Development Studies).

Conflicts of Interest: The authors declare no conflict of interest.

\section{Appendix A}

Table A1. Oral communication apprehension.

\begin{tabular}{|c|c|c|c|c|}
\hline \multicolumn{5}{|c|}{ Between-Subject Factors } \\
\hline & \multicolumn{3}{|c|}{ Value Label } & $\mathbf{N}$ \\
\hline \multirow{5}{*}{ Course } & 1 & \multicolumn{2}{|c|}{ Economics } & 40 \\
\hline & 2 & \multicolumn{2}{|c|}{ Management } & 72 \\
\hline & 3 & \multicolumn{2}{|c|}{ Languages } & 37 \\
\hline & 4 & \multicolumn{2}{|c|}{ Communication Sciences } & 170 \\
\hline & 5 & \multicolumn{2}{|c|}{ Tourism } & 30 \\
\hline \multirow{2}{*}{ Gender } & 1 & \multirow{2}{*}{\multicolumn{2}{|c|}{$\begin{array}{c}\text { Male } \\
\text { Female }\end{array}$}} & 106 \\
\hline & 2 & & & 239 \\
\hline \multicolumn{5}{|c|}{ Descriptive Statistics } \\
\hline \multicolumn{5}{|c|}{ Dependent Variable: Overall CA } \\
\hline Course & Gender & Mean & Std. Deviation & $\mathrm{N}$ \\
\hline \multirow{3}{*}{ Economics } & Male & 65.5385 & 12.23802 & 13 \\
\hline & Female & 76.5185 & 19.33584 & 27 \\
\hline & Total & 72.9500 & 17.95714 & 40 \\
\hline \multirow{3}{*}{ Management } & Male & 65.9667 & 12.21780 & 30 \\
\hline & Female & 70.5238 & 15.50490 & 42 \\
\hline & Total & 68.6250 & 14.31481 & 72 \\
\hline
\end{tabular}


Table A1. Cont.

\begin{tabular}{|c|c|c|c|c|c|}
\hline \multicolumn{6}{|c|}{ Descriptive Statistics } \\
\hline \multicolumn{6}{|c|}{ Dependent Variable: Overall CA } \\
\hline \multirow{3}{*}{ Languages } & Male & 69.9091 & 12.68428 & \multicolumn{2}{|c|}{11} \\
\hline & Female & 80.6538 & 15.33086 & \multicolumn{2}{|c|}{26} \\
\hline & Total & 77.4595 & 15.25450 & \multicolumn{2}{|c|}{37} \\
\hline \multirow{3}{*}{ Communication Sciences } & Male & 62.5366 & 14.96178 & \multicolumn{2}{|c|}{41} \\
\hline & Female & 68.3643 & 16.12739 & \multicolumn{2}{|c|}{129} \\
\hline & Total & 66.9588 & 16.00716 & \multicolumn{2}{|c|}{170} \\
\hline \multirow{3}{*}{ Tourism } & Male & 71.9091 & 22.06107 & \multicolumn{2}{|c|}{11} \\
\hline & Female & 67.2632 & 12.42239 & \multicolumn{2}{|c|}{19} \\
\hline & Total & 68.9667 & 16.39488 & \multicolumn{2}{|c|}{30} \\
\hline \multirow{3}{*}{ Total } & Male & 65.6132 & 14.66682 & \multicolumn{2}{|c|}{106} \\
\hline & Female & 70.8724 & 16.50633 & \multicolumn{2}{|c|}{239} \\
\hline & Total & 69.2751 & 16.13196 & \multicolumn{2}{|c|}{345} \\
\hline \multicolumn{6}{|c|}{ Tests of Between-Subject Effects } \\
\hline \multicolumn{6}{|c|}{ Dependent Variable: Overall CA } \\
\hline Source & Type III Sum of Squares & $\mathrm{df}$ & Mean Square & $\mathrm{F}$ & Sig. \\
\hline Corrected Model & 7484.721 & 9 & 831.636 & 3393 & 0.001 \\
\hline Intercept & $1,026,674.448$ & 1 & $1,026,674.448$ & 4189.304 & 0.000 \\
\hline Course & 2824.703 & 4 & 706.176 & 2882 & 0.023 \\
\hline Gender & 1584.057 & 1 & 1584.057 & 6464 & 0.011 \\
\hline Course $\times$ Gender & 1210.315 & 4 & 302.579 & 1235 & 0.296 \\
\hline
\end{tabular}

Table A2. Post hoc tests: course and homogeneous subsets.

\begin{tabular}{cccc}
\hline \multicolumn{4}{c}{ Overall CA } \\
\hline \multicolumn{3}{c}{ Ryan-Einot-Gabriel-Welsch Range } \\
\cline { 3 - 4 } Course & $\mathbf{N}$ & \multicolumn{3}{c}{ Subset } \\
\cline { 3 - 4 } & & $\mathbf{1}$ & $\mathbf{2}$ \\
\hline Communication Sciences & 170 & 66.9588 \\
\hline Management & 72 & 68.6250 & 68.6250 \\
\hline Tourism & 30 & 68.9667 & 68.9667 \\
\hline Economics & 40 & 72.9500 & 72.9500 \\
\hline Languages & 37 & & 77.4595 \\
\hline Sig. & & 0.319 & 0.074 \\
\hline
\end{tabular}


Table A3. Writing communication apprehension.

\begin{tabular}{|c|c|c|c|c|c|}
\hline \multicolumn{6}{|c|}{ Between-Subject Factors } \\
\hline & & \multicolumn{2}{|c|}{ Value Label } & \multicolumn{2}{|l|}{$\mathbf{N}$} \\
\hline \multirow{5}{*}{ Course } & 1.00 & \multicolumn{2}{|c|}{ Economics } & \multicolumn{2}{|l|}{40} \\
\hline & 2.00 & \multicolumn{2}{|c|}{ Management } & \multicolumn{2}{|l|}{71} \\
\hline & 3.00 & \multicolumn{2}{|c|}{ Languages } & \multicolumn{2}{|l|}{37} \\
\hline & 4.00 & \multicolumn{2}{|c|}{ Communication Sciences } & \multicolumn{2}{|c|}{167} \\
\hline & 5.00 & \multicolumn{2}{|c|}{ Tourism } & \multicolumn{2}{|c|}{30} \\
\hline \multirow{2}{*}{ Gender } & 1.00 & \multicolumn{2}{|r|}{ Male } & \multicolumn{2}{|c|}{106} \\
\hline & 2.00 & \multicolumn{2}{|r|}{ Female } & \multicolumn{2}{|c|}{239} \\
\hline \multicolumn{6}{|c|}{ Descriptive Statistics } \\
\hline \multicolumn{6}{|c|}{ Dependent Variable: Overall WCA } \\
\hline Course & Gender & Mean & Std. Deviation & $\mathrm{N}$ & \\
\hline \multirow{3}{*}{ Economics } & Male & 90.6154 & 12.71835 & 13 & \\
\hline & Female & 83.7407 & 20.80050 & 27 & \\
\hline & Total & 85.9750 & 18.67741 & 40 & \\
\hline \multirow{3}{*}{ Management } & Male & 83.4000 & 14.55927 & 30 & \\
\hline & Female & 87.9024 & 15.74929 & 41 & \\
\hline & Total & 86.0000 & 15.31572 & 71 & \\
\hline \multirow{3}{*}{ Languages } & Male & 86.9091 & 14.12413 & 11 & \\
\hline & Female & 88.3462 & 14.94508 & 26 & \\
\hline & Total & 87.9189 & 14.52465 & 37 & \\
\hline \multirow{3}{*}{ Communication Sciences } & Male & 92.1190 & 14.12868 & 42 & \\
\hline & Female & 89.3520 & 15.78957 & 125 & \\
\hline & Total & 90.0479 & 15.39434 & 167 & \\
\hline \multirow{3}{*}{ Tourism } & Male & 88.6000 & 23.52398 & 10 & \\
\hline & Female & 87.7500 & 14.25289 & 20 & \\
\hline & Total & 88.0333 & 17.46422 & 30 & \\
\hline \multirow{3}{*}{ Total } & Male & 88.5943 & 15.32615 & 106 & \\
\hline & Female & 88.2259 & 16.17133 & 239 & \\
\hline & Total & 88.3391 & 15.89513 & 345 & \\
\hline & Tests of Betwee & Subject $\mathrm{E}$ & fects & & \\
\hline & Dependent Varia & e: Overal & WCA & & \\
\hline Source & Type III Sum of Squares & $\mathrm{df}$ & Mean Square & $\mathrm{F}$ & Sig. \\
\hline Corrected Model & 2136.389 & 9 & 237.377 & 0.938 & 0.492 \\
\hline Intercept & $1,599,156.693$ & 1 & $1,599,156.693$ & 6319.142 & 0.000 \\
\hline Course & 1278.485 & 4 & 319.621 & 1.263 & 0.284 \\
\hline Gender & 42.916 & 1 & 42.916 & 0.170 & 0.681 \\
\hline Course $\times$ Gender & 970.669 & 4 & 242.667 & 0.959 & 0.430 \\
\hline
\end{tabular}




\section{References}

1. Byrne, M.; Flood, B.; Shanahan, D. A Qualitative Exploration of Oral Communication Apprehension. Account. Educ. 2012, 21, 565-581. [CrossRef]

2. Miller, T.C.; Stone, D.N. Public Speaking Apprehension (PSA), Motivation, and Affect among Accounting Majors: A Proof-of-Concept Intervention. Issues Account. Educ. 2009, 24, 265-298. [CrossRef]

3. Byrne, M.; Flood, B.; Shanahan, D. Communication apprehension among business and accounting students in Ireland. Ir. Account. Rev. 2009, 16, 1-19.

4. McCroskey, J.C. The communication perspective. In Avoiding Communication; Daly, J.A., McCroskey, J.C., Eds.; Sage: Beverly Hills, CA, USA, 1984.

5. Richmond, V.P.; McCroskey, J.C. Communication Apprehension, Avoidance and Effectiveness; Gorusch: Scottsdale, AZ, USA, 1989.

6. Simons, K.A.; Riley, T.J. Communication Apprehension in Accounting Majors: Synthesis of Relevant Studies, Intervention Techniques, and Directions for Future Research. Adv. Account. Educ. Teach. Curric. Innov. 2014, 1-32. [CrossRef]

7. McCroskey, J.C.; Beatty, M.J.; Kearney, P.; Plax, T.G. The content validity of the PRCA-24 as a measure of communication apprehension across communication contexts. Commun. Q. 1985, 33, 165-173. [CrossRef]

8. Daly, J.A.; Miller, M.D. The empirical development of an instrument to measure writing apprehension. Res. Teach. Engl. 1975, 9, 242-248.

9. Shanahan, D. High Oral Communication Apprehensives: How Can Students be helped to Reduce Theis Fear of Public Speaking? Ir. J. Acad. Pract. 2013, 2, 9. [CrossRef]

10. Beatty, M.J.; Dobos, J.A. Physiological Assessment. In Avoiding Communication; Daly, J.A., McCroskey, J.C., Ayres, J., Hopf, T., Ayres, D.M., Eds.; Sage: Beverly Hills, CA, USA, 1997; pp. 217-229.

11. Aly, I.M.; Islam, M. Audit of accounting program on oral communications apprehension: A comparative study among accounting students. Manag. Audit. J. 2003, 18, 751-760. [CrossRef]

12. LaRochelle, J.M.; Karpinski, A.C. Racial Differences in Communication Apprehension and Interprofessional Socialization in Fourth-Year Doctor of Pharmacy Students. Am. J. Pharm. Educ. 2016, 80, 8. [CrossRef]

13. Warnock, K.; Curtis, E. Oral Communication Apprehension: A preliminary study of accounting students. In Proceedings of the Irish Accounting and Finance Association Conference, Dublin, Ireland, 15 May 1997; Volume 8.

14. Arquero, J.L.; Hassall, T.; Joyce, J.; Donoso, J.A. Accounting Students and Communication Apprehension: A Study of Spanish and U.K. Students. Eur. Account. Rev. 2007, 16, 299-322. [CrossRef]

15. Ayres, J.; Hopf, T.; Will, A. Are reduction in C.A. an experimental artefact? A Solomon four-group answer. Commun. Q. 2000, 48, 19-26. [CrossRef]

16. Allen, M.; Hunter, J.E.; Donohue, W.A. Meta-analysis of self-report data on the effectiveness of public speaking anxiety treatment techniques. Commun. Educ. 1989, 38, 54-76. [CrossRef]

17. Olivier, L.; Olivier, J. Exploring writing apprehension amongst Afrikaans-speaking first-year students. Read. Writ. 2016, 7, 10. [CrossRef]

18. Huwari, I.F.; Aziz, N.H.A. Writing apprehension in English among Jordanian postgraduate students of Universiti Utara Malaysia. Acad. Res. Int. 2011, 1, 190-198.

19. Daly, J.A. Writing Apprehension and Writing Competency. J. Educ. Res. 1978, 72, 10-14. [CrossRef]

20. Faigley, L.; Daly, J.A.; Witte, S.P. The Role of Writing Apprehension in Writing Performance and Competence. J. Educ. Res. 1981, 75, 16-21. [CrossRef]

21. Daly, J.A. Writing Apprehension in Classroom: Teacher Role Expectancies of the Apprehensive Writer. Res. Teach. Engl. 1979, 13, 37-44.

22. Britt, M.; Pribesh, S.; Hinton-Johnson, K.; Gupta, A. Effect of a Mindful Breathing Intervention on Community College Students' Writing Apprehension and Writing Performance. Community Coll. J. Res. Pract. 2017, 42, 693-707. [CrossRef]

23. Loureiro, M. O Género no Discurso de Opinião na Imprensa Portuguesa; LABCOM/UBI: Covilhã, Portugal, 2014.

24. Lakoff, R. Language, and Woman's Place; Harper and Row: New York, NY, USA, 1975.

25. Key, M.R. Male/Female Language, 2nd ed.; Scarecrow Press: Lanham, MD, USA; London, UK, 1996.

26. Thorne, B.; Henley, N. (Eds.) Language and Sex: Difference and Dominance; Newbury House: Rowley, MA, USA, 1975. 
27. Tannen, D. You Just Don't Understand: Women and Men in Conversation; Harper: New York, NY, USA, 1990.

28. Shawish, J.I.A.; Abderaheem, M.A. An Investigation of Palestinian EFL Majors' Writing Apprehension: Causes and Remedies. 2010. Available online: https://files.eric.ed.gov/fulltext/ED512894.pdf (accessed on 15 November 2019).

29. Masse, M.; Popovich, M. Individual Assessment of Media Writing Student Attitudes: Recasting the Riff and Stacks Writing Apprehension Measure. J. Mass Commun. Q. 2003, 82, 339-355.

30. Pajares, F. Self-efficacy beliefs, motivation, and achievement in writing: A review of the literature. Read. Writ. Q. 2003, 19, 139-158. [CrossRef]

31. Reeves, L.L. Minimizing Writing Apprehension in the Learner-Centered Classroom. Engl. J. 1997, 86, 38. [CrossRef]

32. Martinez, C.T.; Kock, N.; Cass, J. Pain and Pleasure in Short Essay Writing: Factors Predicting University Students' Writing Anxiety and Writing Self-Efficacy. J. Adolesc. Adult Lit. 2011, 54, 351-360. [CrossRef]

33. Gardner, C.T.; Milne, M.; Stringer, C.P.; Whiting, R.H. Oral and written communication apprehension in accounting students: Curriculum impacts and impacts on academic performance. Account. Educ. 2005, 14, 313-336. [CrossRef]

34. Hassall, T.; Joyce, J.; Ottewill, R.; Arquero, J.L.; Donoso, J. Communication apprehension in U.K. and Spanish business and accounting students. Educ. Train. 2000, 42, 93-100. [CrossRef]

35. Shi-Yong, P.; Ali, M.S.S. Communication Apprehension: A Comparison between English Majors and Non-majors in China. Int. J. Appl. Linguist. Engl. Lit. 2015, 4, 190-195. [CrossRef]

36. Dellaportas, S.; Hassall, T. Experiential learning in accounting education: A prison visit. Br. Account. Rev. 2013, 45, 24-36. [CrossRef]

37. Simons, K.; Higgins, M.; Lowe, D. A profile of communication apprehension in accounting majors: Implications for teaching and curriculum revision. J. Account. Educ. 1995, 13, 159-176. [CrossRef]

38. O'Leary, S. Gender and management implications from clearer signposting of employability attributes developed across graduate disciplines. Stud. High. Educ. 2019, 1-20. [CrossRef]

39. O'Leary, S. Graduates' experiences of, and attitudes towards, the inclusion of employability-related support in undergraduate degree programmes; trends and variations by subject discipline and gender. J. Educ. Work 2016, 30, 84-105. [CrossRef]

40. Nabi, G.R.; Bagley, D. Graduates' perceptions of transferable personal skills and future career preparation in the U.K. Career Dev. Int. 1998, 3, 31-39. [CrossRef]

41. Morel, C.M.; Acharya, T.; Broun, D.; Dangi, A.; Elias, C.; Ganguly, N.K.; Gardner, C.; Gupta, R.K.; Haycock, J.; Heher, A.D.; et al. Health Innovation Networks to Help Developing Countries Address Neglected Diseases. Science 2005, 309, 401-404. [CrossRef] [PubMed]

42. Ilias, A.; Razak, M.; Yunus, N. Communication apprehension (C.A.): A case of accounting students. Int. J. Indep. Res. Stud. 2013, 2, 16-27.

43. Shi, X.; Brinthaupt, T.M.; McCree, M. The relationship of self-talk frequency to communication apprehension and public speaking anxiety. Pers. Individ. Differ. 2015, 75, 125-129. [CrossRef]

44. Al-Tamimi, N.O.M. Public Speaking Instruction: Abridge to Improve English Speaking Competence and Reducing Communication Apprehension. Int. J. Linguist. Commun. 2014, 2, 45-68. [CrossRef]

Publisher's Note: MDPI stays neutral with regard to jurisdictional claims in published maps and institutional affiliations.

(C) 2020 by the authors. Licensee MDPI, Basel, Switzerland. This article is an open access article distributed under the terms and conditions of the Creative Commons Attribution (CC BY) license (http://creativecommons.org/licenses/by/4.0/). 